\title{
Metode Timetoken dan Kliping untuk Meningkatkan Partisipasi dan Hasil Belajar Siswa dalam Pelajaran Sosiologi
}

\author{
Dwi Kurniati
}

SMA Negeri 1 Labuhan Deli, Kabupaten Deli Serdang, Sumatera Utara, Indonesia

Diterima Agustus 2016; Disetujui Oktober 2016; Dipublikasikan Desember 2016

\begin{abstract}
Abstrak
Penelitian ini bertujuan untuk meningkatkan partisipasi dan hasil belajar siswa dalam pelajaran sosiologi dengan memadukan metode pemberian tugas time token dan kliping. Pendekatan yang digunakan dalam penelitian ini adalah pendekatan kualitatif dengan jenis penelitian tindakan kelas yang diperluas. Siswa yang dijadikan subyek penelitian adalah siswa kelas XI IS SMA Negeri 1 Labuhan Deli TP 2015-2016. Hasil penelitian menunjukkan Hasil tugas kliping masalah sosial di kelas IX IS 1 menunjukkan jumlah siswa terampil melaksanakan tugas kliping (pencapaian hasil kriteria baik dan sangat baik) sebesar 66,67 $\%$ di siklus 1 dan 72,92 \% disiklus 2. Sementara di IX IS 2 menunjukkan siswa terampil melaksanakan tugas kliping (pencapaian hasil kriteria baik dan sangat baik) sebesar $50 \%$. Di siklus 1 dan 84,37 \% di siklus 2. Keterampilan berbicara melalui time token di kelas XI IS 1 menunjukkan pencapaian hasil kriteria terampil (penc apaian baik dan sangat baik) sebesar 68,75\% di siklus 1 dan 90,63 \% di siklus 2.Di kelas XI IS 2 siswa terampil melaksanakan tugas time token (pencapaian baik dan sangat baik) sebesar $68,75 \%$ di siklus 1 dan $84,37 \%$ di siklus 2 .
\end{abstract}

Kata Kunci: Hasil Belajar; Pelajaran Sosiologi; Metode Pemberian Tugas; Time Token; Kliping.

\begin{abstract}
This study aims to increase participation and student learning outcomes in sociology lesson by combining methods of granting dutytime token and clipping. The approach used in this study is a qualitative approach to the type of classroom action research expanded. Students as research subjects are students of class XI IS SMA Negeri 1 Labuhan Deli TP 2015-2016. The results showed the results of the task of clipping social problems in class IX IS 1 shows the number of students skilled duties clipping (achievement criterion of good and very good) amounted to $66.67 \%$ in cycle 1 and $72.92 \%$ cycled 2. While in IX IS 2 show skilled student clipping duty (achievement criterion of good and very good) by 50\%. In cycle 1 and $84.37 \%$ in cycle 2. Speaking skills through time token in class XI IS 1 shows the achievement of skilled criteria (penc apaian good and excellent) amounted to 68.75\% in cycle 1 and 90.63\% in cycle 2.In the class XI IS 2 skilled student duty time token (and very good achievement) of 68.75\% in cycle 1 and $84.37 \%$ in the second cycle.
\end{abstract}

Keywords: Learning Outcomes; Lessons of Sociology; Method of Providing Duty; Time Token; Scrapbook.

How to Cite: Kurniati, D. (2016). Metode Timetoken dan Kliping untuk Meningkatkan Partisipasi dan Hasil Belajar Siswa dalam Pelajaran Sosiologi, Anthropos: Jurnal Antropologi Sosial dan Budaya, 2 (2) (2016): 175-186.

\footnotetext{
*Corresponding author:

E-mail: kurniawatidwi@yahoo.co.id
}

p-ISSN 2460-4585

e-ISSN 2460-4593 


\section{PENDAHULUAN}

Kelas sebagai tempat berlangsungnya KBM membutuhkan proses pengelolaan secara efektif agar tujuan sebuah pembelajaran dapat tercapai. Pengelolaan kelas yang dimaksudkan adalah bagaimana guru terampil dalam melakukan teknik-teknik mendapatkan umpan balik siswa. Artinya guru harus terampil dalam mensinergikan komponen guru, peserta didik dan bahan yang akan disampaikan. Jika peserta didik sudah memberikan umpan balik secara optimal maka peserta didik dapat menguasai bahan pelajaran secara tuntas.

Dalam teknik mendapatkan umpan balik guru tidak hanya dapat menguasai bahan ajar pokok ketika akan menyampaikan pelajaran. Hal terpenting adalah bahan apersepsi yang harus diberikan kepada peserta didik serta strategi dan metode yang digunakan guru dalam pengajaran. Indikasi umpan balik peserta didik terhadap proses pembelajaran adalah peserta didik mau dan termotivasi melakukan semua kegiatan yang telah dirancang oleh guru sehingga peserta didik dapat menguasai bahan pelajaran secara tuntas dan hasil belajar dapat mencapai baik optimal.

Akan tetapi kesinergian antara komponen guru, murid dan bahan ini sering terabaikan dalam proses pembelajaran. Akibatnya suasana kaku akan muncul, peserta didik tidak memiliki motivasi dalam belajar, peserta didik tidak berpartisipasi dalam kegiatan pembelajaran sehingga hasil belajar rendah dan bermuara kepada kegagalan pengajaran. Karena bagaimana pun juga keberhasilan pengajaran ditentukan oleh penguasaan peserta didik terhadap bahan pelajaran yang disampaikan oleh pendidik.

Berdasarkan pengalaman peneliti (guru) selama ini, dalam pembelajaran sosiologi yang dilakukan di kelas XI SMAN 1 Labuhan Deli peneliti masih menemukan masalah belajar di atas. Guru masih sering mengandalkan verbalisme dalam menyampaikan materi. Sehingga hasil belajar peserta didik tidak menunjukkan penguasaan bahan pelajaran secara tuntas. Saat UH peserta didik masih banyak yang mengalami ketidaktuntasan.
Berkenaan dengan hal di atas, peneliti berusaha mengatasi masalah belajar ini dengan melakukan inovasi pembelajaran.

Inovasi ini diawali oleh penelitian tindakan kelas di kelas XI IS 1 TP 2015-2016. Saat itu untuk mengatasi masalah belajar di kelas peneliti melakukan penelitian tindakan kelas yang memadukan metode pemberian tugas kliping dan time token dalam kegiatan pembelajaran. Setelah tindakan di kelas XI IS 1 menunjukkan peningkatan hasil belajar, tindakan juga diperlakukan di kelas XI IS 2. Judul yang diambil dalam inovasi ini adalah : Upaya meningkatkan partisipasi dan hasil belajar siswa pada pelajaran sosiologi di SMA Negeri 1 Labuhan Deli.

\section{METODE PENELITIAN}

Tempat Penelitian tindakan kelas ini dilakukan di kelas XI IS SMA Negeri 1 Labuhan Deli, Kabupaten Deli Serdang di semester ganjil tahun pelajaran 2015-2016. Jumlah rombongan belajar XI IS adalah 2 rombongan belajar. Setiap rombongan berjumlah 32 orang. Penelitian ini menggunakan metode penelitian tindakan kelas yang diperluas. Artinya tindakan diberlakukan untuk 2 kelas, yaitu kelas XI IS 1 dan XI IS 2 SMA N 1 Labuhan Deli TP 2015-2016.Subjek penelitian ini adalah seluruh siswa kelas XI IS1 dan XI IS 2 SMAN 1 Labuhan Deli pada T.P. 2015-2016.

Untuk variabel penelitian terdiri atas variabel tindakan dan variabel penelitian. Variabel penelitian dari PTK ini adalah hasil belajar siswa. Sementara variabel tindakan dari PTK ini adalah metode pemberian tugas time token dan kliping. Teknik pengumpulan data adalah observasi dan tes. Teknik observasi dilakukan selama KBM dengan menggunakan lembar pengamatan untuk mengetahui aktifitas siswa selama KBM berlangsung. Hal-hal yang diobservasi mencakup keterlibatan siswa dalam kegiatan pembelajaran dalam tugas kliping dan time token. Yaitu bagaimana pencapaian hasil dalam melaksanakan tugas kliping dan time token. 
Instrumen penelitian ini adalah rubrik untuk mengobservasi hasil kerja penugasan kliping dan time token. Standar rubrik terdiri atas 3 kriteria, yaitu mengungkapkan isu masalah kliping, argumen dalam menjelaskan ide, serta penggunaan kalimat dan kerapian. Untuk setiap kriteria memiliki skor tingkatan yang dimulai dari skor terendah 1 sampai skor tertinggi 5. Hasil skor di kategorikan atas kriteria sangat baik ( $90-100$ ), kriteria baik (80 - 89), dan kriteria cukup (70 -79). Kriteria baik dan sangat baik menjadi indikator siswa terampil. Berikut penjelasan skor untuk setiap kriteria :

Tabel 3.1 Standar dan Kriteria Kliping

\begin{tabular}{|l|l|l|}
\hline No. & Standar & Kriteria \\
\hline 1 & & Mengungkapkan isu masalah kliping \\
\hline & 5 & Mengungkapkan isu masalah kliping jelas \\
& 4 & Mengungkapkan isu masalah kliping jelas, tetapi terlalu panjang \\
& 2 & Mengungkapkan isu masalah kliping terlalu panjang dan tidak jelas \\
& 1 & Mengungkapkan isu masalah kliping tidak jelas \\
\hline 2 & & Tidak mengungkapkan isu kliping \\
\hline & 5 & Argumen fakta jelas dan mengungkapkan bukti-bukti \\
& 4 & Argumen fakta kurang jelas \\
& 3 & Argumen fakta dan bukti lemah \\
& 2 & Argumen fakta tidak mengungkapkan bukti \\
\hline 3 & 1 & \\
\hline & 5 & Penggunaan kalimat dan kerapian \\
& 4 & Tersusun dan ada kesalahan kecil \\
& 3 & Tidak efektif, tidak jelas dan tersusun \\
& 2 & Tidak ektif, tidak jelas dan kurang tersusun \\
& 1 & Tidak efektif, tidak jelas dan tidak tersusun \\
\hline
\end{tabular}

Sementara analisis terhadap hasil time token guru menggunakan standar kriteria sebagai berikut :

Tabel 3.2. Standar dan Kriteria Time Token

\begin{tabular}{|l|l|l|}
\hline No. & Standar & Kriteria \\
\hline 1. & & Pengungkapan Ide dan Argumen \\
\hline & 5 & Sesuai referensi, efektif dan jelas \\
& 4 & Sesuai referensi, ada kesalahan kecil \\
& 3 & Tidak sesuai referensi, deskripsi jels \\
& 2 & Tidak sesuai referensi, deskripsi ada kesalahan kecil \\
\hline 2. & 1 & Tidak sesuai referensi dan deskripsi tidak jelas \\
\hline & 5 & Sikap dalam mengkomunikasikan \\
& 4 & percaya diri dan sikap sempurna \\
& 3 & percaya diri dan kurang sempurna \\
& 2 & tidak percaya diri dan bahasa jelas \\
& 1 & tidak percaya diri dan tidak jelas \\
\hline
\end{tabular}

Standar rubrik kegiatan time token menggunakan 2 rubrik, yaitu : 1. pengungkapan ide dan argumen, 2. sikap dalam mengkomunikasikan. Setiap rubrik memiliki tingkatan skor 1 sampai dengan 5 . Hasil skor dikategorikan atas kriteria sangat baik (90 $100)$, kriteria baik (80 - 89), kriteria cukup (7079). Kriteria sangat baik dan baik menujukkan indikator siswa terampil.
Instrumen tes berkenaan dengan kemampuan pemahaman siswa setelah melaksanakan kegiatan pembelajaran berupa soal pilihan berganda dan uraian yang diberikan untuk pre test dan post test.

Untuk memaknai data penelitian digunakan teknik analisis kualitatif dan presentase sederhana. Analisis data dilakukan secara kualitatif. Artinya analisis data sudah 
mulai dilakukan ketika PTK ini dilaksanakan. Semua data yang diperoleh melalui observasi dicatat dan dikategorikan oleh peneliti. Datadata yang sudah dikategorikan akan dimasukkan ke dalam tabel sederhana sehingga lebih mudah dibaca dan disimpulkan. Untuk keberhasilan penelitian ditetapkan kriteria berikut: 1) Pencapaian daya serap klasikal $\geq 75$ $\%$ sesudah dilakukannya tindakan. 2) Interval ketuntasan Belajar Klasikal mencapai $\geq 75 \%$. 3) Hasil laporan tugas time token dan kliping menunjukkan pencapaian $\geq 75 \%$ atau lebih dari jumlah siswa mencapai hasil terampil atau dalam kriteria sangat baik (nilai 90-100) dan baik ( nilai 80-89)

\section{HASIL DAN PEMBAHASAN}

Penelitian ini dilakukan untuk mengetahui pengaruh metode pemberian tugas time token dan kliping dalam upaya meningkatkan partisipasi dan hasil belajar siswa dalam pelajaran sosiologi di kelas XI IS SMA N 1 Labuhan Deli. Penelitian ini dilakukan di 2 kelas. Yaitu kelas XI IS 1 dan XI IS 2 TP 2015-2016.

Hasil pengamatan di kelas XI-IS1 dan XIIS2 sebelum dilakukan tindakan menunjukkan tingkat partisipasi yang rendah. Peserta didik belum mengikuti kegiatan dalam KBM dan belum memberikan partisipasi aktif. Ketika guru meminta gagasan peserta didik tentang masalah sosial setelah dilaksanakan kegiatan mengamati (kegiatan pertama dalam $5 \mathrm{M}$ di pendekatan scientific) tidak ada peserta didik yang berani memberikan gagasannya. Komunikasi bersifat 1 arah. Peserta didik hanya duduk dan mendengarkan. Tidak ada respon balik yang diberikan peserta didik kepada pendidik ketika dilaksanakan tanya jawab. Sementara tugas untuk membaca materi masalah sosial dan mencari contoh di masyarakat sudah diberikan pada akhir pertemuan materi sebelumnya.

Di bawah ini merupakan deskripsi perolehan nilai peserta didik kelas XI IS 1 dan XI IS2 sebelum dilakukan tindakan.

Tabel 4.1. Data hasil belajar kelas XI IS 1 sebelum tindakan

\begin{tabular}{|c|l|l|c|c|}
\hline No. & Hasil test & Keterangan & Jumlah siswa & Persentase \\
\hline 1. & Nilai $<73$ & Tidak tuntas & 19 & 59,37 \\
2. & Nilai 73 & Tuntas & 6 & 18,76 \\
3. & Nilai 80- 90 & Tuntas & 7 & 21,87 \\
4. & Nilai 100 & Tuntas & ---- & ---- \\
\hline \multicolumn{2}{|l|}{ Jumlah } & $\mathbf{3 2}$ & $\mathbf{1 0 0}$ \\
\hline
\end{tabular}

Berdasarkan data di atas hasil belajar siswa XI kurang karena jumlah siswa yang tidak tuntas IS 1 sebelum tindakan dilakukan menunjukan mencapai 19 orang dari 32 atau sekitar 59,37 pencapaian keberhasilan berada dalam tingkat \%.

Tabel 4.2. Data hasil belajar kelas XI IS 2 sebelum tindakan

\begin{tabular}{|c|l|l|l|l|}
\hline No. & Hasil test & Keterangan & Jumlah siswa & Persentase \\
\hline 1. & Nilai $<73$ & Tidak tuntas & 24 & 75 \\
2. & Nilai 73 & Tuntas & 5 & 15,62 \\
3. & Nilai $80-90$ & Tuntas & 3 & 9,38 \\
4. & Nilai 100 & Tuntas & ---- & ---- \\
\hline \multicolumn{2}{|l|}{ Jumlah } & $\mathbf{3 2}$ & $\mathbf{1 0 0}$ \\
\hline
\end{tabular}

Berdasarkan data di atas hasil belajar siswa sebelum tindakan dilakukan di kelas XI IS 2 menunjukan pencapaian keberhasilan berada dalam tingkat kurang karena jumlah siswa yang tidak tuntas berjumlah 24 orang dari 32 jumlah peserta didik atau sekitar $75 \%$.

Implementasi Metode Pemberian Tugas Time Token dan Kliping pada Deskripsi Siklus 1 adalah Perencanaan dan Pelaksanaan Siklus 1.
Sebelum tindakan penelitian dilakukan, peneliti membuat perencanaan penelitian dengan mempersiapkan instrumen penelitian berupa : 1). RPP, Skenario pembelajaran, lembar kerja siswa, 2). soal tes, lembar peta konsep, lembar observasi kegiatan siswa serta lembar observasi guru. Untuk melihat kevalidan soal tes, peneliti menguji kevalidan dengan menggunakan penganalisisan logika. Soal-soal 
tes yang akan diberikan kepada peserta didik sebagai alat ukur hasil belajar dianalisis berdasarkan konstruksi soal. Dimana soal dicocokkan dengan aspek berpikir yang ingin dicapai dalam materi melalui kisi-kisi soal.

Setelah kegiatan perencanaan, peneliti melaksanaan tindakan dengan menjalankan desain pembelajaran metode pemberian tugas time token dan kliping. Disain tindakan yang sudah dibuat dilaksanakan di kelas XI IS 1 dan XI IS 2 dalam 6 kali pertemuan untuk 2 siklus. Adapun implementasi metode pemberian tugas dan time token adalah sebagai berikut: Pertemuan siklus 1 dilaksanakan pada tanggal 1, 8, dan 15 Oktober 2015 dengan waktu 2 x 45'. Untuk kelas XI IS 1 dilaksanakan pada jam ke 34. Sementara di kelas XI IS 2 pada jam ke 7-8. Kegiatan di siklus 1 ditutup dengan UH pada tanggal 29 Oktober 2015.

Kegiatan yang dilaksanakan dari kegiatan apersepsi sampai dengan penutup adalah di awal pembelajaran peneliti mengkondisikrtan kelas memastikan semua yang dibutuhkan dalam pembelajaran lengkap dan siap digunakan. Diantaranya kondisi sikap dan kenyamanan siswa untuk mengikuti pelajaran, alat pembelajaran dan buku siap di dalam kelas. Setelah semuanya dalam posisi siap, peneliti mulai melakukan kegiatan pembelajaran sebagai berikut: 1) Guru menginformasikan materi yang akan dipelajari, dan menyampaikan tujuan pembelajaran, 2) Guru melakukan tanya jawab kepada siswa tentang kelompok kelompok sosial dan konsekuensinya dalam masyarakat Indonesia sebagai prasyarat materi. 3) Guru menjelaskan kegiatan pembelajaran yang harus diikuti oleh siswa. 4) Guru memberikan apersepsi banyak masalah yang terjadi di Indonesia sebagai konsekuensi keanekaragaman di Indonesia. 5) Sebelum melakukan kegiatan pengamatan (mendengarkan) guru memberikan pre test kepada siswa. 5) Siswa mendengarkan uraian deskripsi konflik POSO sebagai konflik horizontal di Indonesia. 6) Setelah mengikuti kegiatan mendengarkan guru meminta siswa memberikan pertanyaan tentang apa yang didengarkan,sebagai contoh apakah dampak yang dirasakan oleh masyarakat dengan adanya konflik Poso? 7) Guru menjelaskan sedikit tentang materi pengertian masalah sosial, faktor penyebab terjadinya masalah sosial. 8) Guru membagi siswa atas kelompok kecil, dan setiap kelompok memberikan satu contoh masalah sosial di dalam masyarakat yang akan dikliping dan dieksplorasi, berkaitan dengan penjelasan fakta dan faktor yang menyebabkan masalah sosial tersebut. 9) Guru meminta setiap kelompok untuk berdiskusi dan mengeksplorasi contoh masalah sosial tersebut, mencari kliping yang berkaitan dengan masalah sosial tersebut dan menggali referensi. 10) Memberikan penguatan bahwa pertemuan ke-2 akan dilakukan kegiatan mengasosiasi dan megkomunikasikan kerja kelompok. 11) Pada pertemuan ke 2 guru menjelaskan bahwa pada pertemuan ke-2 akan dilaksanakan kegiatan mengasosiasi tentang apa yang sudah dieksplor dengan menggali referensi dan mengkomunikasikannya. 12) Siswa mulai bekerja dalam kelompok, menganalisis sebuah contoh masalah sosial yang sudah dipilih oleh kelompok dan mengkomunikasikan hasil kerjanya. 13) Saat itu guru juga melakukan kegiatan pengamatan bersama elaborator. 14) Kegiatan pada pertemuan ke-2 ditutup dengan menyimpulkan materi secara bersama-sama antara guru dan siswa secara klasikal. 15) Pada pertemuan ke 3 kegiatan diawali dengan kegiatan Guru melakukan kegiatan tanya jawab tentang materi pertemuan sebelumnya. 16) Guru mengingatkan bahwa kegiatan pada pertemuan ketiga adalah kegiatan time token. Guru menjelaskan skenario kegiatan. Setiap siswa diberikan 2 kartu. Setiap kartu digunakan siswa untuk mengemukakan argumen dari masalah yang peneliti (dalam hal ini guru) berikan. Kesempatan berbicara dibatasi oleh durasi waktu 2 menit. Siswa yang masih memiliki kartu harus memberikan pendapat. Siswa yang sudah menghabiskan satu kartu dapat menggunakan kartu kedua. 17) Siswa mulai melaksanakan tugas time token dan guru melaksanakan pengamatan. 18) Akhir siklus yang dilaksanakan guru mengingatkan kembali materi yang sudah dibahas pada pertemuan 
sebelumnya dengan melakukan kegiatan tanya jawab. Setelah itu peneliti melaksanakan kegiatan post test untuk mengukur hasil belajar di siklus 1.

Tabel 4.3. Hasil pencapaian penugasan kliping siklus 1 kelas XI IS 1
\begin{tabular}{|l|c|l|l|l|}
\hline No. & \multicolumn{2}{|c|}{ Kelompok } & Nilai Pencapaian & Kriteria Hasil Kerja \\
\hline 1. & I $\quad: \quad 5$ orang & $80-86$ & Baik \\
\hline 2. & II $\quad: \quad 5$ orang & $80-86$ & Baik \\
\hline 3. & III $: \quad 5$ orang & $80-86$ & Baik \\
\hline 4. & IV $:$ & 6 orang & $73-79$ & Cukup \\
\hline 5. & V $:$ & 5 orang & $73-79$ & Cukup \\
\hline 6. & VI $:$ & 6 orang & $87-93$ & Sangat Baik \\
\hline
\end{tabular}

Tabel di atas menunjukkan pencapaian hasil dengan kriteria cukup (nilai 70-79) sebesar 2 kelompok atau 33,33\%, kriteria baik ( nilai 80-89) sebesar 3 kelompok $50 \%$, kriteria sangat baik (nilai 90 - 100 ) sebesar 1 kelompok atau 16,67 \%. Artinya di siklus 1 dari 32 orang siswa masih ada yang belum terampil melaksanakan tugas analisa kliping.

Tabel 4.4. Hasil pencapaian penugasan kliping siklus 1 kelas XI IS 2

\begin{tabular}{|c|c|c|c|}
\hline No. & Kelompok & Nilai Pencapaian & Kriteria Hasil Kerja \\
\hline 1. & I : 5 orang & 85 & Baik \\
\hline 2. & II : 5 orang & 78 & Baik \\
\hline 3. & III : 5 orang & 79 & Cukup \\
\hline 4. & IV : 6 orang & 70 & Cukup \\
\hline 5. & $\mathrm{~V}: 5$ orang & 70 & Cukup \\
\hline 6. & VI : 6 orang & 80 & Baik \\
\hline
\end{tabular}

Tabel di atas menunjukkan menit untuk berbicara bagi beberapa siswa pencapaian hasil dengan kriteria cukup (nilai 70-79) sebesar 3 kelompok atau $50 \%$, kriteria baik ( nilai 80-89) sebesar 3 kelompok $50 \%$. Artinya di siklus 1 dari 32 orang siswa masih dari peserta didik peserta didik yang belum terampil melaksanakan tugas analisa kliping.

Selain pengamatan terhadap pelaksanaan dan hasil tugas kliping, peneliti (guru pelaksana tindakan) juga melakukan pengamatan terhadap tugas time token.Selama pelaksanaan time token disiklus 1 masih banyak siswa yang menunjukkan ketidakpercayaan diri. Guru banyak memberikan arahan untuk menumbuhkan keberanian siswa. Waktu 2 adalah waktu yang terlalu lama. Waktu yang diberikan untuk penugasan time token adalah 90 menit. Di siklus 1 ini dalam kegiatan time token kelas masih diwarnai dengan tindakan stimulus guru untuk menumbuhkan keberanian. Karena masih banyak siswa yag belum memiliki rasa keberanian yang tinggi, peneliti membatasi siswa yang memiliki keberanian untuk menggunakan 1 kartu terlebih dahulu dan memberikan kesempatan kepada teman yang belum merasa yakin dengan kemampuan diri nya untuk berbicara secara lisan. Berikut tabel hasil pencapaian aktifitas siswa dalam time token :

Tabel 4.5. Hasil Pencapaian Kegiatan Time Token siklus 1 kelas XI IS 1

\begin{tabular}{|l|l|l|c|l|}
\hline No. & Nilai & Kriteria & Jumlah siswa & Persentase \\
\hline 1. & $60-69$ & Kurang & 4 & 12,50 \\
\hline 2 & $70-79$ & Cukup & 6 & 18,75 \\
\hline 3. & $80-89$ & Baik & 13 & 40,63 \\
\hline 4. & $90-100$ & Sangat baik & 9 & 28,12 \\
\hline
\end{tabular}

Berdasarkan hasil pengamatan keterampilan berbicara melalui time token di kelas XI IS 1 menunjukkan pencapaian hasil kriteria baik ( nilai 80 - 89 ) adalah 13 orang atau 40,63\% dan sangat baik (nilai 90-100) 9 orang atau sebesar 28,12. Di time token siklus 1 ini dari 32 siswa XI IS 1, siswa yang berani dan percaya diri serta terampil mengajukan pendapat berjumlah 9 orang. Siswa yang percaya diri tetapi kurang terampil berbicara 
berjumlah 13 orang. Siswa yang belum memiliki percaya diri tetapi ingin mencoba setelah diberikan motivasi oleh guru berjumlah 6 orang. Sementara siswa yang belum memiliki rasa percaya diri sama sekali sampai kegiatan berakhir berjumlah 4 orang. Di akhir kegiatan guru memberikan kesempatan dan kepercayaan kepada mereka untuk menggunakan time token nya di pertemuan berikutnya. Hasil pengamatan untuk aktifitas time token di siklus 1 kelas XI IS 2 adalah sebagai berikut:

Tabel 4.6. Hasil Pencapaian Kegiatan Time Token siklus 1 kelas XI IS 2

\begin{tabular}{|l|l|l|c|l|}
\hline No. & Nilai & Kriteria & Jumlah siswa & Persentase \\
\hline 1. & $60-69$ & Kurang & 2 & 6,25 \\
\hline 2 & $70-79$ & Cukup & 8 & 25 \\
\hline 3. & $80-89$ & Baik & 20 & 62,5 \\
\hline 4. & $90-100$ & Sangat baik & 2 & 6,25 \\
\hline
\end{tabular}

Dari tabel di atas menunjukkan lembar kerja siswa, soal pretest, peta konsep, keterampilan berbicara melalui time token di lembar observasi siswa serta lembar observasi kelas XI IS 2 pencapaian hasil kriteria baik ( guru. Setelah itu peneliti dan observer nilai 80 - 89) adalah 20 orang atau $62,5 \%$ dan sangat baik ( nilai 90-100) hanya 2 orang atau sebesar 6,25. Di time token siklus 1 ini dari 32 siswa XI IS 2, siswa yang berani dan percaya diri serta terampil mengajukan pendapat berjumlah 2 orang. Siswa yang percaya diri tetapi kurang terampil berbicara berjumlah 20 orang. Siswa yang belum memiliki percaya diri tetapi ingin mencoba setelah diberikan motivasi oleh guru berjumlah 8 orang. Sementara siswa yang belum memiliki rasa percaya diri sama sekali sampai kegiatan berakhir berjumlah 2 orang.

Setelah kegiatan post test dilaksanakan, kegiatan berikutnya adalah peneliti bersama observer merefleksi seluruh kegiatan yang sudah dilakukan di siklus 1. Pada kegiatan refleksi ini peneliti bersama observer mengidentifikasi kelemahan-kelemahan dan melakukan perbaikan di siklus 2. Adapun kelemahan-kelemahan yang dijumpai di siklus 1 adalah : (1) masih banyak siswa belum percaya diri saat melaksanakan kegiatan time token. Sehingga saat kegiatan time token guru banyak memberikan motivasi dengan memanggil siswa seperti "taufik, bagaimana, mau coba ? silahkan . Atau " Ayo Dony, silahkan coba jangan takut dan malu." (2). Masih ada siswa yang tidak melibatkan diri dalam mengeksplorasi dan mengasosiasi, sehingga ketika melaksanakan time token tidak percaya diri.

Sebelum tindakan penelitian siklus 2 dilakukan peneliti mempersiapkan instrumen penelitian berupa RPP, skenario pembelajaran, berdiskusi menganalisis hasil refleksi siklus 1 untuk dilakukan perbaikan disiklus 2 .

Berdasarkan hasil refleksi di siklus 1, perbaikan yang dilakukan disiklus 2 adalah : 1) Tugas kliping tidak dikerjakan secara kelompok. Tetapi individu. Kelompok digunakan individu untuk mengasosiasi apa yang sudah dieksplorasi secara individu. Perubahan ini didasari oleh tujuan agar semua individu terlibat dalam mengeksplorasi referensi. 2) Dalam menjelaskan kegiatan yang akan dilakukan guru terlebih dahulu mengemukakan contoh. Perubahan ini didasari oleh tujuan agar siswa lebih yakin dengan apa yang sudah dibuatnya dan percaya diri untuk mengkomunikasikannya. Siklus 2 dilaksanakan pada tanggal 5 sampai dengan 19 November 2015.

Adapun tindakan yang dilakukan di siklus 2 meliputi: 1) Guru mengkondisikan kelas memastikan semua yang dibutuhkan dalam pembelajaran lengkap dan siap digunakan. 2) Guru memberikan motivasi kalau dipertemuan sebelumnya siswa dapat menunjukkan keterampilannya dalam menganalisis melalui kliping dan time token maka dalam pertemuan kali ini siswa lebih baik lagi. 3) Guru memberikan apersepsi banyak halhal yang dapat dianalisis untuk melihat alasan kenapa sebuah masalah sosial dapat muncul. 4) Guru menjelaskan kaitan materi pertemuan sebelumnya dengan materi hari ini. 5) Guru menjelaskan tujuan pembelajaran. 6) Guru meminta salah seorang siswa 
mengkomunikasikan fakta masalah kenakalan remaja. 7) Guru memberikan pertanyaan kenapa itu dapat terjadi, dan meminta siswa memberikan argumen menjawab pertanyaan tersebut. 8) Guru menjelaskan secara singkat teori-teori yang dapat digunakan dalam menganalisis penyebab terjadinya sebuah masalah sosial. 9) Guru memberikan tugas kepada siswa untuk menggali referensi yang ada mengenai teori-teori dalam menganalisis masalah sosial dan membuat review ke dalam matrik secara individu dan menggunakan kelompok sebagai sarana diskusi. 10) Guru mengingatkan untuk pertemuan berikutnya siswa membawa gambar ataupun artikel dari suratkabat atau internet yang menggambarkan masalah sosial. 11) Guru mengingatkan siswa tentang materi teori-teori dalam menganalisis masalah sosial melalui tanya jawab. 12) Siswa bekerja mengerjakan analisis kliping. 13) Guru melakukan kegiatan observasi. 14) Guru mengingatkan siswa bahwa pembelajaran pertemuan berikutnya akan dilakukan kegiatan time token. 15) Guru mengkondisikan kelas. 16) Guru memberikan apersepsi dengan mengingatkan kembali pengetahuan siswa tentang teori-teori yang dapat digunakan dalam menganalisis masalah sosial. 17) Siswa melaksanakan kegiatan time token mengenai kliping yang sudah dikerjakan. 18) Guru menyimpulkan materi secara klasikal. Hasil observasi siklus 2 menunjukkan data partisipasi belajar setelah tindakan sebagai berikut :

Tabel 4.7. Hasil pencapaian penugasan kliping siklus 2 kelas XI IS 1

\begin{tabular}{|l|l|l|l|}
\hline No. & Jumlah individu & Nilai Pencapaian & Kriteria Hasil Kerja \\
\hline 1. & 5 & $73-79$ & Cukup \\
\hline 2. & 22 & $80-86$ & Baik \\
\hline 3. & 5 & $87-93$ & Sangat Baik \\
\hline
\end{tabular}

Tabel di atas menunjukkan pencapaian menunjukkan walaupun kriteria cukup masih hasil dengan kriteria cukup (nilai 70-79) dijumpai di siklus 2, tetapi jumlah persentase sebesar 5 orang atau 15,63\%, kriteria baik ( sudah berkurang dibandingkan disiklus 1. nilai 80-89 ) sebesar 22 orang 68,74 \% Artinya keterampilan siswa untuk menganalisis kriteria sangat baik (nilai 90 - 100 ) sebesar 5 kliping sudah mulai terbentuk di siklus 2 untuk orang. atau 15,63\% . Data tabel di atas kelas XI IS 1

Tabel 4.8. Hasil pencapaian penugasan kliping siklus 2 kelas XI IS 2

\begin{tabular}{|l|l|l|l|}
\hline No & Kelompok & Nilai Pencapaian & Kriteria Hasil Kerja \\
\hline 1. & 3 & $73-79$ & Cukup \\
\hline 2. & 25 & $80-86$ & Baik \\
\hline 3. & 4 & $87-93$ & Sangat Baik \\
\hline
\end{tabular}

Tabel di atas menunjukkan pencapaian hasil dengan kriteria cukup (nilai 70-79) sebesar 3 orang atau 9,37\%, kriteria baik ( nilai 80-89) sebesar 25 orang atau 78,12 \%. Dan kriteria sangat baik ( nilai 90-100) sebesar 4 orang atau $12,5 \%$. Artinya di siklus 2 dari 32 orang siswa kelas XI IS 2 mulai terampil melaksanakan tugas analisa kliping.

Untuk pengamatan terhadap Kegiatan time token disiklus 2 pelaksanaan nya lebih tenang dan lancar. Siswa sudah mulai dapat menggunakan waktu secara efektif. Siswa sudah memiliki kepercayaan diri. Siswa bahkan berebut untuk maju ke depan kelas melakukan time token. Berikut tabel hasil pencapaian aktifitas siswa dalam time token :

Tabel 4.9 Hasiln Pencapaian Kegiatan Time Token siklus 2 kelas XI IS 1

\begin{tabular}{|l|l|l|c|c|}
\hline No. & Nilai & Kriteria & Jumlah siswa & Persentase \\
\hline 1. & $70-79$ & Cukup & 3 & 9,37 \\
\hline 2. & $80-89$ & Baik & 17 & 53,13 \\
\hline 3. & $90-100$ & Sangat baik & 12 & 37,5 \\
\hline
\end{tabular}

Berdasarkan hasil pengamatan keterampilan berbicara melalui time token di kelas XI IS 1 menunjukkan pencapaian hasil kriteria baik ( nilai 80 - 89 ) adalah 17 orang atau 53,13\% dan sangat baik ( nilai 90-100) 12 orang atau sebesar $37,5 \%$. Di time token 
siklus 2 ini dari 32 siswa XI IS 1, siswa yang belum memiliki percaya diri tetapi ingin mencoba setelah diberikan motivasi oleh guru berjumlah 3 orang. Untuk hasil pengamatan aktifitas time token di siklus 2 kelas XI IS 2 adalah sebagai berikut:

Tabel 4.10. Hasil Pencapaian Kegiatan Time Token siklus 1 kelas XI IS 2

\begin{tabular}{|l|l|l|c|c|}
\hline No & Nilai & Kriteria & Jumlah siswa & Persentase \\
\hline 1. & $60-69$ & Kurang & 1 & 3,12 \\
\hline 2 & $70-79$ & Cukup & 4 & 12,5 \\
\hline 3. & $80-89$ & Baik & 22 & 68,75 \\
\hline 4. & $90-100$ & Sangat baik & 5 & 15,62 \\
\hline
\end{tabular}

Dari tabel di atas menunjukkan keterampilan berbicara melalui time token di kelas XI IS 2 pencapaian hasil kriteria baik ( nilai $80-89$ ) adalah 22 orang atau $68,75 \%$ dan sangat baik ( nilai 90-100 ) meningkat menjadi 5 orang atau sebesar $15,62 \%$. Di time token siklus 2 ini dari 32 siswa, siswa yang belum memiliki percaya diri tetapi ingin mencoba setelah diberikan motivasi oleh guru berjumlah 4 orang atau $12,5 \%$. Sementara siswa yang belum memiliki rasa percaya diri sama sekali sampai kegiatan berakhir berjumlah 1 orang.

Berikut data hasil belajar siswa disiklus 1 dan siklus 2 dalam pembelajaran materi masalah sosial setelah dilakukan tindakan.

Tabel 4.11. Data Tingkat Keberhasilan Belajar Siklus 1 kelas XI IS 1

\begin{tabular}{|l|l|l|l|l|}
\hline No & Hasil test & Keterangan & Jumlah siswa & Persentase \\
\hline 1. & Nilai $<70$ & Tidak tuntas & 2 & $6,25 \%$ \\
\hline 2. & Nilai 75 & Tuntas & 3 & $9,37 \%$ \\
\hline \hline 3. & Nilai $80-90$ & Tuntas & 23 & $71,88 \%$ \\
\hline 4. & Nilai 100 & Tuntas & 4 & $12,5 \%$ \\
\hline Jumlah & $\mathbf{3 2}$ & $\mathbf{1 0 0 \%}$ \\
\hline
\end{tabular}

Data pada tabel di atas menunjukkan 12,5\%. Fakta ini menjelaskan bahwa setelah bahwa setelah dilakukannya tindakan di kelas dilakukannya tindakan yang dapat XI IS 1, hanya 2 siswa atau 6,25 \% yang tidak mempengaruhi upaya peningkatan hasil belajar tuntas. Siswa yang dapat mencapai nilai 80-90 siswa di kelas XI IS 1. Sementara hasil belajar berjumlah 23 orang atau 71,88 \%. Dan siswa siswa setelah tindakan siklus 1 di kelas XI IS 2 yang dapat menyelesaikan tes dengan hasil dapat di lihat dalam tabel berikut: sempurna atau 100 berjumlah 4 orang atau

Tabel 4.12.Data Tingkat Keberhasilan Belajar Siklus 1 kelas XI IS 2

\begin{tabular}{|l|l|l|l|l|}
\hline No & Hasil test & Keterangan & Jumlah Siswa & Persentase \\
\hline 1. & Nilai $<70$ & Tidak tuntas & 4 & $12,5 \%$ \\
\hline 2. & Nilai 75 & Tuntas & 8 & $25 \%$ \\
\hline 3. & Nilai 80-90 & Tuntas & 18 & $56,25 \%$ \\
\hline 4. & Nilai 100 & Tuntas & 2 & $6,25 \%$ \\
\hline Jumlah & $\mathbf{3 2}$ & $\mathbf{1 0 0 \%}$ \\
\hline
\end{tabular}

Data pada tabel di atas menunjukkan yang dapat menyelesaikan tes dengan hasil bahwa setelah dilakukannya tindakan di kelas sempurna atau 100 hanya berjumlah 2 orang XI IS 2, masih ada 4 orang siswa atau 12,5 atau 6,25 \%. Fakta ini menjelaskan bahwa \%yang tidak mencapai ketuntasan . 8 orang tindakan dapat memperbaiki hasil belajar siswa siswa atau sebesar $25 \%$ mencapai nilai pas di kelas XI IS 2. KKM. Siswa yang dapat mencapai nilai 80-90 berjumlah 18 orang atau 56,25\%. Dan siswa

Untuk hasil belajar disiklus 2 setelah tindakan adalah sebagai berikut :

Tabel 4.13. Data Tingkat Keberhasilan Belajar Siklus 2 Kelas XI IS 1

\begin{tabular}{|l|l|l|l|l|}
\hline No. & Hasil tes & Keterangan & Jumlah siswa & Presentase \\
\hline 1. & Nilai 73 & Tuntas & 2 & 6,25 \\
\hline
\end{tabular}




\begin{tabular}{|l|l|l|l|l|}
\hline 2. & Nilai 75-90 & Tuntas & 19 & 59,37 \\
\hline 3 & Nilai 100 & Tuntas & 11 & 34,38 \\
\hline
\end{tabular}

Data pada tabel di atas menunjukkan berjumlah 19 orang atau $59,37 \%$ dan bahwa setelah dilakukannya tindakan siklus 2 mendapatkan nilai 100 berjumlah 11 orang di kelas XI IS 1, semua siswa meraih hasil tes atau 34,38\%. Sementara hasil belajar setelah dengan kategori tuntas dengan distribusi nilai tindakan siklus 2 di kelas XI IS 2 adalah sebagai sebagai berikut : siswa mendapatkan nilai 73 berikut:

berjumlah 2 orang atau 6,25\%, nilai 75 - 90

Tabel 4.14. Data Tingkat Keberhasilan Belajar Siklus 2 Kelas XI IS 2

\begin{tabular}{|l|l|l|l|c|}
\hline No. & Hasil tes & Keterangan & Jumlah siswa & Presentase \\
\hline 1. & Nilai 73 & Tuntas & 1 & 3,13 \\
\hline 2. & Nilai $75-90$ & Tuntas & 26 & 81,25 \\
\hline 3 & Nilai 100 & Tuntas & 5 & 15,62 \\
\hline
\end{tabular}

Data pada tabel di atas menunjukkan disiklus I juga menunjukkan belum semua bahwa setelah dilakukannya tindakan siklus 2 kelompok berhasil menyusun gagasan di kelas XI IS 2, semua siswa meraih hasil tes kelompok secara tepat dan memuaskan. Pada dengan kategori tuntas dengan distribusi nilai saat kegiatan time token dilakukan disiklus 1 sebagai berikut : siswa mendapatkan nilai 73 berjumlah 1 orang atau 3,13\%, nilai 75 - 90 berjumlah 26 orang atau $81,25 \%$ dan mendapatkan nilai 100 berjumlah 5 orang atau $15,62 \%$.

Tujuan dari penelitian ini adalah mengupayakan peningkatan partisipasi dan hasil belajar siswa dengan menggunakan metode pemberian tugas time token dan kliping. Dari hasil penelitian menunjukkan bahwa pemberian tindakan memberikan pengaruh terhadap upaya meningkatkan partisipasi dan hasil belajar siswa di kelas XI IS SMA N 1 Labuhan Deli TP 2015-2016. Seberapa besar pengaruh tindakan dalam meningkatkan partisipasi dan hasil belajar dapat dilihat pada uraian berikut .

Untuk partisipasi belajar dengan tindakan yang dilakukan membuat peserta didik terlibat dalam kegiatan belajar mengajar. Karena siswa dikondisikan bekerja menggali informasi dari referensi yang ada mengenai contoh masalah sosial dan melakukan kegiatan mengasosiasi hasil eksplorasi di dalam kelompok untuk membuat kesimpulan kelompok.

Ketika tindakan dalam siklus 1 masih banyak peserta didik yang belum berani dan percaya diri mengemukakan gagasannya di dalam kelompok. Masih ada siswa yang tidak terlibat aktif dan menyerahkan sepenuhnya kepada teman kelompok. Hasil kerja kelompok peserta didik juga masih kurang percaya diri dalam mengemukakan gagasan dan pikiran. Sangat kelihatan di siklus I peserta didik masih dibebani oleh rasa takut salah, dan bingung karena durasi waktu yang diberikan. Suara guru memberikan stimulus dengan menggunakan kalimat "ayo, siapa lagi yang ingin mengemukakan gagasannya silahkan ke depan, jangan takut salah. Bukan kah sudah membaca referensi?" masih selalu terdengar.

Tetapi di siklus II kondisi kelas saat proses pembelajaran berlangsung sudah lebih tenang. Tindakan yang dilakukan berupa kegiatan individu dan mengkondisikan individu terlibat aktif dalam kegiatan kliping. Begitu juga ketika kegiatan sharing hasil kliping individu dengan kelompok. Ketika kegiatan time token dilaksanakan peserta didik mulai antusias untuk maju ke depan. Suara yang terdengar bukan lagi suara guru memberikan stimulus. Tetapi suara siswa yang meminta untuk terlebih dahulu maju dari temannya. Kondisi ini dijumpai di dua kelas yang berbeda. Seperti bu "habis ni Eko ya". "Habis Eko Tiur bu". "Bu kami berlima berdiri aja nunggu di depan. Seperti antri ya bu. Ketika pergantian siswa berbicara, suasana yang terlihat adalah lari-lari kecil siswa dari bangku untuk maju ke depan.

Pembelajaran dengan metode pemberian tugas time token dan kliping juga memberikan pengalaman yang menantang bagi siswa, serta dapat menumbuhkan percaya diri siswa. 
Keterlibatan siswa dalam proses pembelajaran juga terjadi. Berdasarkan hasil angket yang diberikan kepada peserta didik setelah kegiatan pembelajaran dilakukan, peserta didik merasa tertantang dengan kegiatan pembelajaran. Hal ini disebabkan karena mereka diharuskan membaca referensi dan mengungkapkan pemahaman mereka tentang referensi yang ada secara lisan. Tetapi menurut peserta durasi waktu yang terbatas membuat mereka lupa tentang apa yang akan mereka ungkapkan.
Percaya diri mereka juga muncul. Selain itu menurut siswa penilaian guru menjadi lebih objektif. Guru lebih objektif melihat peserta didik yang mampu dan peserta didik yang tidak mampu.

Pembelajaran yang bermakna melalui tugas kliping dan time token mempengaruhi hasil belajar siswa. Seberapa besarkah peningkatan hasil belajar peserta didik dapat dilihat dalam tabel berikut:

Tabel 4.15. Perolehan hasil belajar di sebelum dan sesudah tindakan

\begin{tabular}{|c|l|l|l|l|l|l|}
\hline \multirow{2}{*}{} & \multicolumn{3}{|c|}{ XI IS 1 } & \multicolumn{3}{c|}{ XI IS 2 } \\
\cline { 2 - 7 } & Pra & Siklus 1 & Siklus 2 & Pra & Siklus 1 & Siklus 2 \\
\hline Jlh Nilai & 2188 & 2848 & 2850 & 2025 & 2518 & 2701 \\
\hline R & 68,38 & 89,00 & 89,06 & 63,28 & 78,68 & 84,40 \\
\hline
\end{tabular}

Dari tabel di atas dapat dilihat 2 perolehan nilai rata-rata hasil belajar naik peningkatan hasil belajar di kelas XI IS 1 jika sekitar $7 \%$.

dibandingkan antara sebelum tindakan dengan Dari hasil belajar setelah dilakukan setelah dilakukan tindakan adalah selisih 20,62 tindakan baik di kelas XI IS 1 ataupun XI IS2 atau sekitar $30 \%$. Untuk kelas XI IS 2 selisih interval Ketuntasan Belajar klasikal dan Daya 15,40 atau sekitar $24 \%$. Di kelas XI IS 1 selisih serap klasikal dapat dilihat pada grafik perolehan rata-rata tidak begitu jauh berbeda berikut: antara siklus 1 dan siklus 2. Tetapi di kelas XI IS

Grafik 1. Hasil Ketuntasan dan Daya

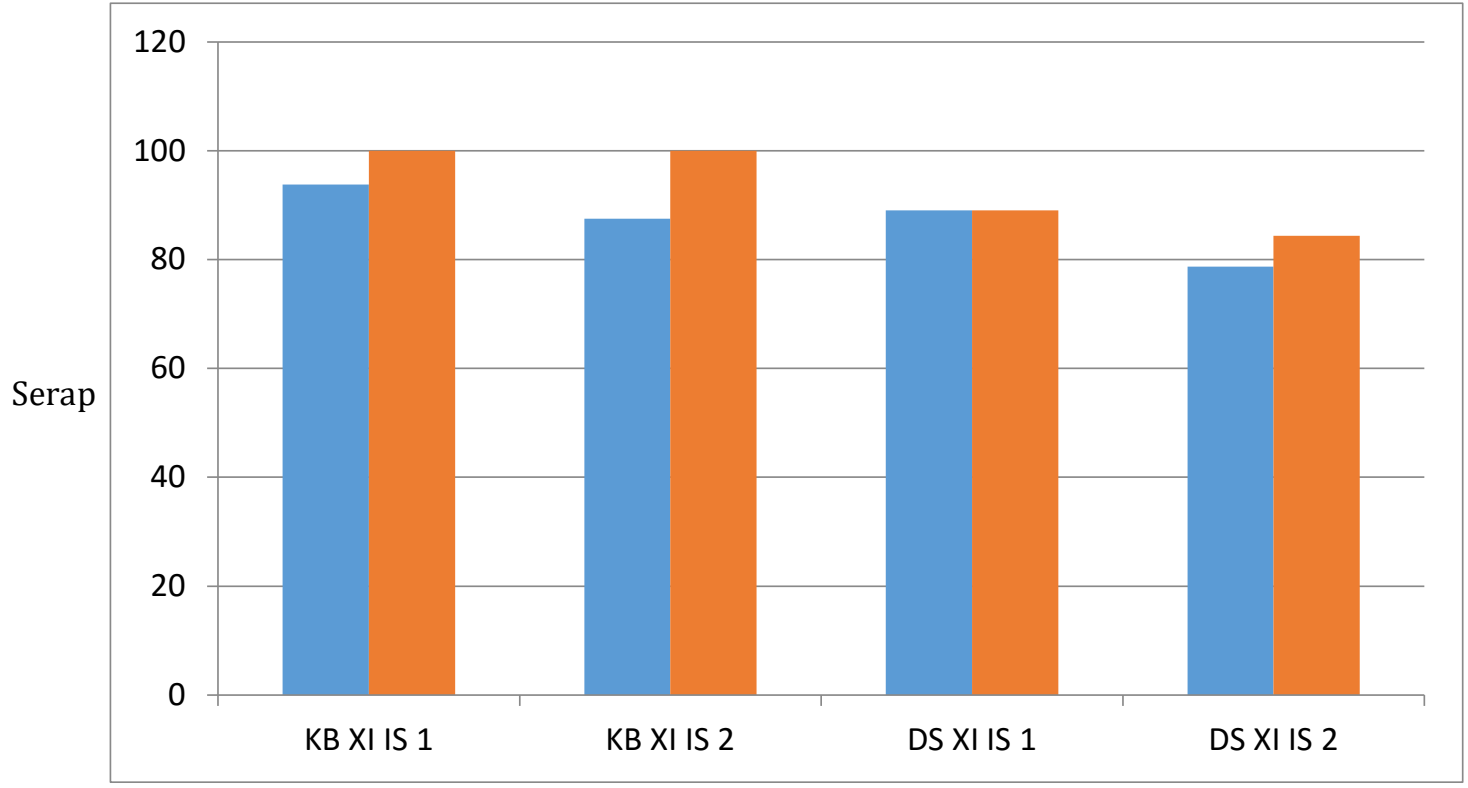

KB : KETUNTASAB BELAJAR

DS ; DAYA SERAP

BITU ; SIKLUS 1

MERAH ; SIKLUS 2

Data grafik di atas menunjukkan interval KB (ketuntasan belajar klasikal ) ataupun DS (daya serap ) berada pada kategori baik karena berada pada interval $\geq 75 \%$. 


\section{KESIMPULAN}

Daya serap kelas XI IS 1 disiklus 1 adalah $89,00 \%$. Sementara disiklus 2 ketuntasan adalah 89, 06 \%. 1. Daya serap kelas XI IS 2 disiklus 1 adalah 78,68 \%. Sementara disiklus 2 daya serap adalah $84,40 \%$ dan $84,40 \%$.

Ketuntasan belajar klasikal menunjukkan pencapaian 93,75 \% disiklus 1 dan 100\% disiklus 2 di kelas XI IS 1 . Kelas XI IS 2 ketuntasan belajar klasikal menunjukkan pencapaian 87,5\% di siklus 1 dan $100 \%$ di siklus 2.

Hasil tugas kliping masalah sosial dikelas IXIS 1 menunjukkan jumlah siswa terampil melaksanakan tugas kliping (pencapaian hasil kriteria baik dan sangat baik) sebesar 66,67\% di siklus 1 dan 72,92 \% disiklus 2. Sementara di IX IS 2 menunjukkan siswa terampil melaksanakan tugas kliping (pencapaian hasil kriteria baik dan sangat baik ) sebesar $50 \%$. Di siklus 1 dan $84,37 \%$ di siklus 2 .
Keterampilan berbicara melalui time token di kelas XI IS 1 menunjukkan pencapaian hasil kriteria terampil ( pencapaian baik dan sangat baik ) sebesar $68,75 \%$ di siklus 1 dan 90,63\% di siklus 2.. Di kelas XI IS 2 siswa terampil melaksanakan tugas timetoken (pencapaian baik dan sangat baik) sebesar $68,75 \%$ di siklus 1 dan $84,37 \%$ di siklus 2 .

\section{DAFTAR PUSTAKA}

Istarani. 2011. 8 Model Pembelajaran Inovatif. Medan : Media Persada.

Cahyo, A.N. 2013. Panduan Aplikasi Teori-Teori Belajar Mengajar. Yogyakarta : DivaPress.

Djamarah, S.B. 2006. Strategi Belajar Mengajar. Jakarta, Rineka Cipta.

Munthe, B. 2013. Desain Pembelajaran. Yogyakarta : Pustaka Insan Madani.

Putra, S.R. 2013. Desain Belajar Mengajar Kreatif Berbasis Sains. Yogyakarta : DivaPress.

Yaumi, M. 2013. Prinsip-PrinsipDesain Pembelajaran. Jakarta.Kencana. 